\title{
Chemical control of Albizia and mesquite in two selected pastures in southwestern Puerto Rico'
}

\author{
Lii-Chyuan Liü
}

\begin{abstract}
Field experiments were carried out during 1988-89 at the AES-UPR Lajas substation and on a private farm in its vicinity to evaluate the efficacy of imazapyr and picloram in the control of Albizia and mesquite in two selected pastures. Both herbicides were applied by the following methods: basal bark, cut stump, frill treatment and injection. Basal bark was the most effective method for albizia control when using imazapyr at $0.237 \mathrm{~V} / 3.8 \mathrm{~L}$ application; injection, the least effective. Cut stump was the most effective method when using imazapyr at $0.355 \mathrm{~L} / 3.8 \mathrm{~L}$; frill treatment, the least effective. Basal application was the most effective method when using an undiluted formulation of picloram; cut stump, the least effective. For mesquite control, cut stump was the most effective method when using imazapyr at both rates of application. Cut stump was the most effective method of picloram application; basal bark, the least effective. The mortality data of both affected species were analyzed on the basis of individual herbicide, irrespective of method of application. A significantly higher percentage of mortality of both species was registered with picloram than with imazapyr.
\end{abstract}

\section{RESUMEN}

Control químico de Albicia y bayahonda

Se realizaron dos experimentos de campo en 1988-89 en la subestación de Lajas y una finca privada de Lajas para evaluar imazapyr y picloram para combatir los árboles albizia y bayahonda (Prosopis juliflora) en dos pastos. Ambos herbicidas se aplicaron por los siguientes métodos: aplicación a base de la corteza, trafamiento al focón, tratamiento en tajos alredededor del tronco e inyección a troncos barrenados. Para controlar albizia, el método más eficaz con imazapyr a razón de 0.237 I./3.8 I. fue la aplicación a base de la corteza; el menos eficaz fue la inyección. El método más eficaz de imazapyr a razón de $0.355 \mathrm{I} . / 3.8 \mathrm{l}$. fue el tratamiento al tronco cortado; el menos fue el tratamiento de tajos alrededor del tronco. El método más eficaz de picloram fue tratar la base de la corteza; el menos efectivo el tratamiento al tronco cortado. Para el control de bayahonda, el método más eficaz de imazapyr a ambas dosis fue el tronco cortado; ninguno de los otros tres métodos fue eficaz. El método más eficaz de picloram fue el tratamiento al tronco cortado y el menos la aplicación a base de la corteza. Por lo general, la mortalidad de ambas especies fue más alta con picloram que con imazapyr.

'Manuscript submitted to Editorial Board 13 February 1990.

2Plant Physiologist, Department of Crop Protection. 


\section{INTRODUCTION}

Albizia (Albizia procera) and mesquite (Prosopis juliflora) are two woody species invading pastures and range lands in Puerto Rico. Albizia is found mostly in the humid area of the island (4), whereas mesquite is confined to the southern coastal and inner valley regions. Both species interfere with grazing, lower the yield and quality of forage grasses and subsequently render the pastures ungrazable.

Chemical means have been investigated for the control of resistant broadleaf weeds $(5,8,9)$ and undesirable grasses $(6,8,10)$ in local pastures. However, the only research on the use of herbicides for controlling trees of several species in Puerto Rican forests was done by Bovey et al. (3). They found that a herbicide mixture 2,4,5-T and picloram reduced the regrowth of trees of several species more effectively than contact herbicides such as cacodylic acid and paraquat. No research has been done locally on the use of herbicides to control unwanted trees in our pastures. On the basis of demonstrated efficacy of imazapyr for tree control $(1,2)$, this herbicide was evaluated against a standard tree killer, picloram, for the control of albizia and mesquite. This paper summarizes findings obtained in 1988-89 at two sites in Lajas to determine the efficacy of imazapyr $\{( \pm)$-2-[4,5-dihydro-4-(1-methyl)-5-Oxo-1H-imidazol-2-Y1]-3pyridinecarboxylic acid\} and picloram (4-amino-3,5,6-trichloro-2pyridinecarboxylic acid) on the control of albizia and mesquite.

\section{MATERIALS AND METHODS}

Albizia control experiment

This experiment was initiated 21 September 1988 at the AES-UPR Lajas substation. The soil was a Fraternidad clay (Vertic, Udic Chromusterts, very fine montmorillonitic, isohyperthermic). Treatments included imazapyr (CHOPPER) at $0.237 \mathrm{~L} / 3.8 \mathrm{~L}$ and $0.355 \mathrm{~L} / 3.8 \mathrm{~L}$, picloram (Tordon RTU) in undiluted formulation and an untreated check. Each herbicide was applied by four different methods: basal bark, cut stump, frill treatment and injection.

Five adult trees were selected and marked for respective treatments one week before the application of each herbicide. Each treatment was replicated two times and arranged in a complete randomized design. The experiment consisted of 16 treatments including three rates and four methods of application. Guinea grass (Panicum maximum) was the dominant pasture species. The basal bark method consisted of mixing 237 $\mathrm{ml}$ or $355 \mathrm{ml}$ of CHOPPER in 3.8L of diesel oil and then spraying this mixture around the bark from root collar up to a height of $1.2 \mathrm{~m}$ with a backpack sprayer. For the frill treatment, cuts were made from 5.0 to $7.5 \mathrm{~cm}$ apart around the trunk with a machete. The cut surface was then sprayed with a mixture of CHOPPER and water. For the injection method was a portable generator-powered drill was used to make holes 
1 inch apart around the tree trunk. The 1-ml portion of CHOPPER and water mixture was injected into each hole with a small plastic syringe. The cut stump method consisted of cutting off the standing tree about $0.3 \mathrm{~m}$ above the soil level with a gasoline-powered chain-saw and then spraying immediately the cut surface with CHOPPER mixed with water at the indicated rates. All TORDON RTU treatments were similarly applied undiluted. For the injection method, TORDON RTU was injected into each of the drilled holes, which were $5.1 \mathrm{~cm}$ instead of $2.5 \mathrm{~cm}$ apart as in the case of the CHOPPER injection.

The mortality of treated albizia trees, including untreated check trees, was recorded for the various treatments at 3,6,9 and 12 months after the initial herbicide application. The mortality of albizia trees was expressed in terms of percentage; the data were analyzed statistically.

\section{Mesquite control experiment}

The mesquite experiment was established 7 October 1988 on a private farm. The major pasture species was buffel grass (Cenchrus ciliaris). The soil was a Pozo Blanco loam (9) which has a much lighter texture than the Fraternidad clay of the Lajas substation. The same herbicide treatments and methods of application as in the albizia experiment were used. Five adult mesquite trees were similarly selected and different treatments applied. The same herbicide treatments were arranged in a complete randomized design with two replications. The mortality of

TABLE 1.-Effect of imazapyr and picloram on mortality of albizia at it time periods

\begin{tabular}{|c|c|c|c|c|c|c|}
\hline \multirow[b]{2}{*}{ Treatment } & & \multirow{2}{*}{$\begin{array}{l}\text { Method of } \\
\text { application }\end{array}$} & \multicolumn{4}{|c|}{ Mortality at the end of } \\
\hline & & & Dec. 88 & Mar. 89 & June 89 & Sept. 89 \\
\hline Imazapyr & $0.23771 / 3.81$ & Basal bark & 40 & 40 & 40 & 20 \\
\hline$"$ & $"$ & Cut stump & 20 & 20 & 20 & 20 \\
\hline$"$ & $"$ & Frill & 20 & 20 & 20 & 20 \\
\hline$"$ & $"$ & Injection & 10 & 10 & 10 & 10 \\
\hline Imazapyr & $0.3551 / 3.81$ & Basal bark & 40 & 40 & 30 & 30 \\
\hline$"$ & $"$ & Cut stump & 50 & 40 & 40 & 40 \\
\hline$"$ & $"$ & Frill & 10 & 10 & 10 & 10 \\
\hline$"$ & $"$ & Injection & 20 & 20 & 20 & 20 \\
\hline Picloram & & Basal bark & 100 & 100 & 100 & 100 \\
\hline$"$ & & Cut stump & 70 & 70 & 70 & 70 \\
\hline$"$ & & Frill & 80 & 80 & 80 & 80 \\
\hline$"$ & & Injection & 90 & 90 & 90 & 90 \\
\hline Check & & Basal bark & 0 & 0 & 0 & 0 \\
\hline$"$ & & Cut stump & 0 & 0 & 0 & 0 \\
\hline$"$ & & Frill & 0 & 0 & 0 & 0 \\
\hline$"$ & & Injection & 0 & 0 & 0 & 0 \\
\hline $\operatorname{LSD}(0.05)$ & & & 17 & 15 & 17 & 18 \\
\hline
\end{tabular}




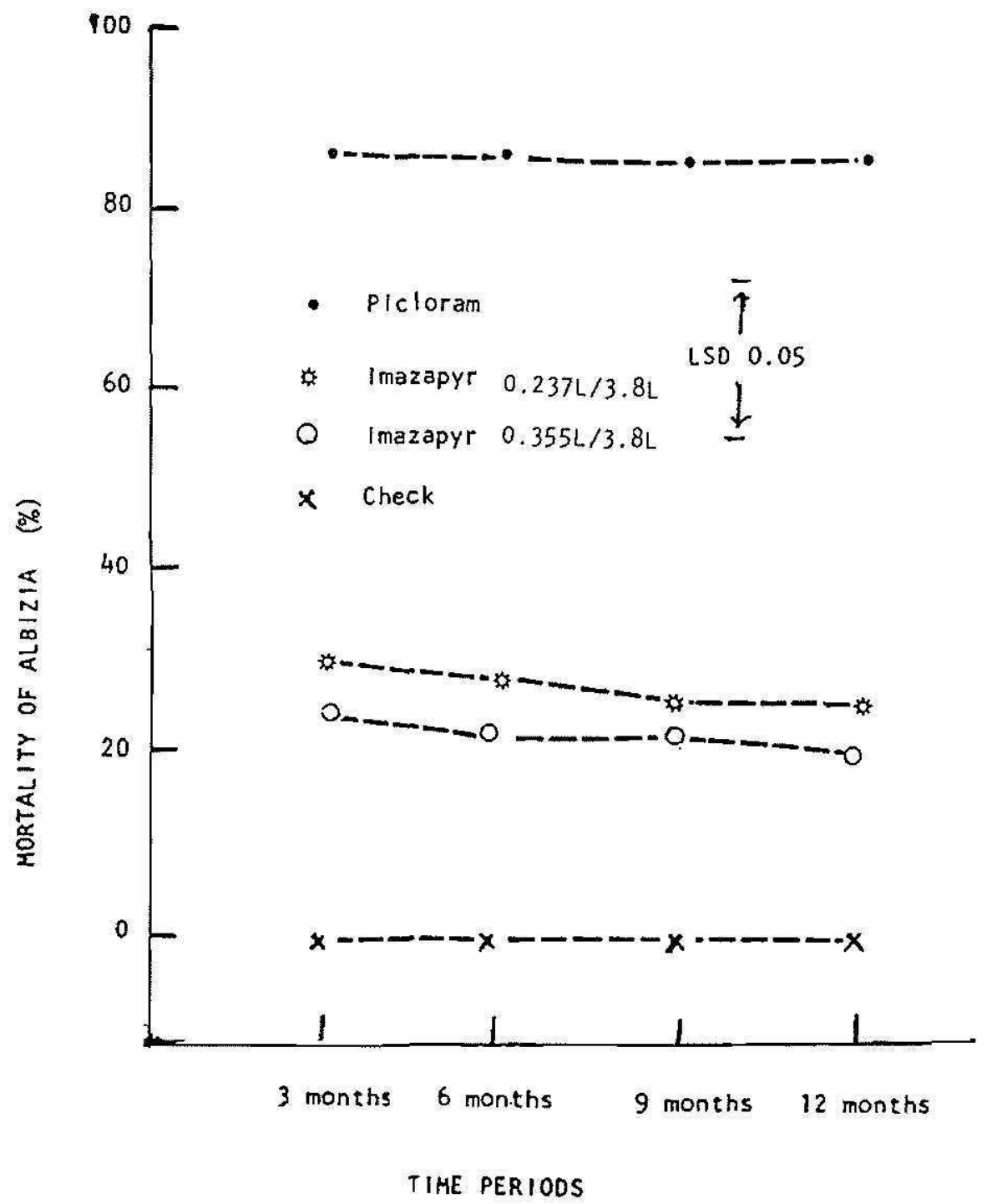

FIG. 1.-Mortality of albizia as affected by different herbicides irrespective of method of application.

treated mesquites, including untreated check trees, was recorded as in the albizia experiment and the data analyzed statistically.

\section{RESULTS}

Albizia control experiment

Basal bark was the most effective method of application of imazapyr at $0.237 \mathrm{~L} / 3.8 \mathrm{~L}$ by the end of 12 months (30\% of mortality, table 1 ); least effective for the same period was injection (10\% mortality). Cut stump was the most effective method of application of imazapyr at $0.355 / 3.8 \mathrm{~L}$ ( $40 \%$ mortality); least effective was the frill treatment (10\% mortality). Basal bark was also the most effective method of application of picloram (100\% mortality). The least effective was cut stump (70\% mortality). When the data in table 1 were analyzed on the basis of individual her- 
bicides, irrespective of method of application, a significantly higher percentage of albizia mortality was obtained with picloram than with imazapyr at different time periods (fig. 1). For imazapyr treatments, there appeared to be a slight descending trend in mortality with increased time periods. This descending trend did not hold true in case of picloram. Even though the data are not shown here, at the end of 1 month after the initial herbicide, most picloram-treated trees died. However, those trees treated with imazapyx at either rate remained unaffected over the same period.

\section{Mesquite control experiment}

Cut stump was the most effective method of application of imazapyr both at $0.237 \mathrm{~L} / 3.8 \mathrm{~L}$ and $0.355 \mathrm{~L} / 3.8 \mathrm{~L}$ by the end of 12 months $(30 \%$ and $60 \%$ mortality, respectively (table 2). The three other methods were ineffective ( $0 \%$ mortality). Cut stump was the most effective method of picloram application (100\% mortality): the least effective was basal bark ( $0 \%$ mortality). Again, when data were analyzed on an individual herbicide, irrespective of method of application, a higher percentage of mesquite mortality was obtained with picloram than with imazapyr at different time periods (fig. 2). The descending trend in mesquite mortality with increased time periods was evident with both rates of imazapyr application but not with picloram.

TABLE 2.-Effect of imazapyr and picloram on mortality of mesquite at a 4 time periods

\begin{tabular}{|c|c|c|c|c|c|c|}
\hline \multirow[b]{2}{*}{ Treatment } & & \multirow{2}{*}{$\begin{array}{l}\text { Method of } \\
\text { application }\end{array}$} & \multicolumn{4}{|c|}{ Mortality in the beginning of } \\
\hline & & & Jan. 89 & Apr. 89 & July 89 & Oct. 89 \\
\hline Imazapyr & $0.23771 / 3.81$ & Basal bark & 0 & 0 & 0 & 0 \\
\hline$"$ & " & Cut stump & 80 & 30 & 30 & 30 \\
\hline$"$ & $"$ & Frill & 10 & 10 & 10 & 10 \\
\hline$"$ & $"$ & Injection & 0 & 0 & 0 & 0 \\
\hline Imazapyr & $0.3551 / 3.81$ & Basal bark & 0 & 0 & 0 & 0 \\
\hline$"$ & $"$ & Cut stump & 100 & 80 & 60 & 60 \\
\hline$"$ & $"$ & Frill & 0 & 0 & 0 & 0 \\
\hline$"$ & $"$ & Injection & 0 & 0 & 0 & 0 \\
\hline Picloram & & Basal bark & 0 & 0 & 0 & 0 \\
\hline " & & Cut stump & 100 & 100 & 100 & 100 \\
\hline$"$ & & Frill & 40 & 40 & 40 & 40 \\
\hline$"$ & & Injection & 60 & 60 & 60 & 60 \\
\hline Check & & Basal bark & 0 & 0 & 0 & 0 \\
\hline$"$ & & Cut stump & 0 & 0 & 0 & 0 \\
\hline$"$ & & Frill & 0 & 0 & 0 & 0 \\
\hline$"$ & & Injection & 0 & 0 & 0 & 0 \\
\hline $\operatorname{LSD}(0.05)$ & & & 17 & 28 & 28 & 28 \\
\hline
\end{tabular}




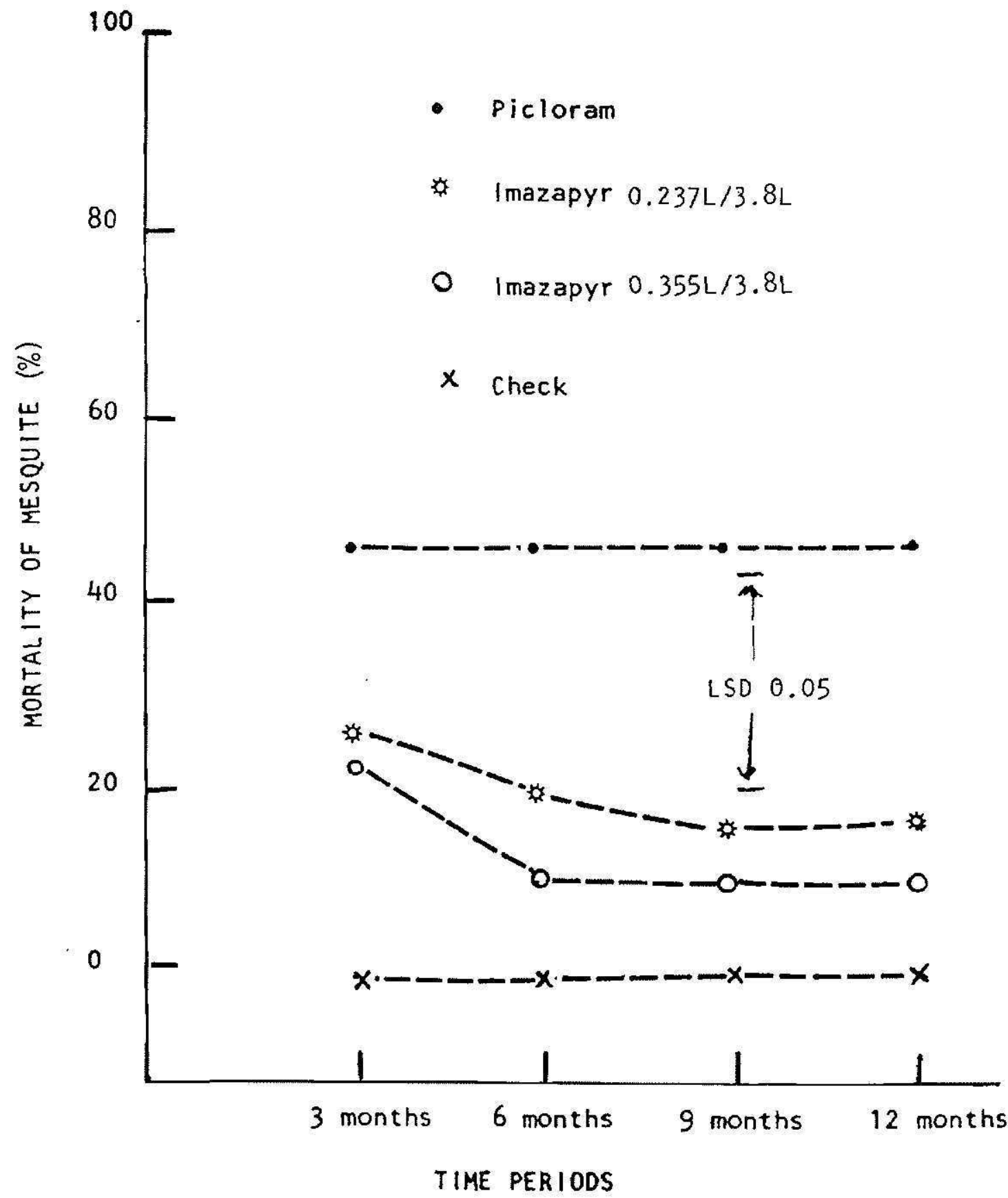

Frg. 2.-Mortality of mesquite as affected by different herbicides irrespective of method of application.

\section{DISCUSSION}

The effectiveness of imazapyr and picloram as tree killers depends to a good extent on their method of application. On the basis of the finding herein reported, neither picloram nor imazapyr would be effective for controlling mesquite if they were applied according to the basal bark method. On the other hand, both herbicides were moderately to highly effective for albizia control when applied using the basal bark method. 
The different herbicide responses of these two woody species could be attributed either to the fact that mesquite has a harder bark and wood tissue than albizia (7), or that there may be a different detoxifying mechanism involved. Thus, the quantity of picloram entry and amount to be detoxified by both species could vary significantly. Imazapyr is known to act with greatest effectiveness through foliar and soil absorption (11). Unfortunately, these methods of application were not included in this study.

The cut stump method for applying both herbicides proved to be highly effective in most instances for controlling both species. On the basis of this study, an increased rate of imazapyr cut stump application would most probably improve mesquite control.

\section{LITERATURE CITED}

1. Beardmore, R. A., 1988. Update of arsenical herbicide performance. Proc. South. Weed Sci. Soc. 41: 331.

2. - 1989. Imazapyr: A Tod for Use in Forestry and Noxious Weed Control Programs. Proc. South. Weed Sci. Soc. 42: 333.

3. Bovey, R. W., C. C. Dowler and J. P. Díaz-Colón, 1969. Response of Tropical Vegetation to Herbicides. Weed Sci. 17: 290-95.

4. Chinea-Rivera, J. D., 1987. Dinámica de poblaciones experimentales de Albizia procera, un árbol de Puerto Rico de la zona húmeda. Memoria de Soc. Puertorriqueña de Ciencias Agricolas. p. 20.

5. González-Ibáñez, J., 1977. Control of resistant broadleaf species in Puerto Rico pastures using mixtures of 2,4-D with picloram and Dicamba. J. Agric. Univ. P. R. 61 (3): 326-31.

6. - 1984. Glyphosate for weed control in Puerto Rican pastures. J. Agric. Univ. P. R. 68 (3): $289-96$.

7. Little, E. L. and F. H. Wadsworth, 1964. Common trees of Puerto Rico and Virgin Islands. Agric. Handb. No. 249 USDA 148 and 166.

8. Lugo, María de L., L. C. Liu and C. E. Ortíz, 1989. Effect of four herbicides on the establishment and forage yield of stargrass in Puerto Rico. J. Agric. Univ. P. R. 73 (2): 149-53.

9. Spain, G. L. and A. Sotomayor-Ríos, 1976. Effect of two triazine compounds on the establishment and forage yield of pangola grass. J. Agric. Univ. P. R. 60 (3): 201-06.

10. Weed Sic. Soc. of America. 1989. Herbicide Handbook, Sixth ed. 210. 